\title{
Climate change in the Western Balkans and EU Green Deal: status, mitigation and challenges
}

Sandi Knez ${ }^{1}$, Snežana Štrbac $2^{2^{*}}$ and Iztok Podbregar ${ }^{3}$

\begin{abstract}
Background: The European Commission (EC), based on the European Green Deal (2019) and the Recovery plan for Europe (2021), envisages investing 30\% of the budget in climate-related programs, projects, and initiatives, which clearly shows Europe's commitment to becoming the first climate-neutral region by 2050. Activities are also planned for countries that are not members of the European Union (EU), which require complex changes in the field of legislation, strategic planning, implementation, and monitoring. To successfully plan short-term and long-term activities on these grounds, it is necessary to have a realistic picture of the state of climate change in each country-as they spill over into the entire region of Europe. The main objective of this paper is to answer the following questions: (i) is climate change observed in Western Balkans? (ii) how are certain sectors vulnerable to climate change in Western Balkans? (iii) what are the climate change adaptation strategies in the six countries of the Western Balkans? The answers to these questions can help in planning activities and initial alignment of Western Balkan countries with the EU plan to achieve net zero greenhouse gas (GHG) emissions by 2050.

Main body: The main results of the research show that in all countries of the region, the average annual temperature increased by $1.2^{\circ} \mathrm{C}$ compared to 1970 , with stabilization and the beginning of the decline which can be expected around 2040. The main reasons for climate change in the region are: industry, energy, and heating sector based on coal exploitation, low energy efficiency, etc.

Conclusions: It can be concluded that Croatia as a member of the EU has adopted, and other five Western Balkans countries are in the process of adopting the necessary regulations and strategies towards climate change mitigation, but the implementation of specific activities is at a low level. The reason for this most often lies in the insufficient commitment of decision-makers to make significant changes in the field of climate change transition (lower level of economic development, lack of investment, and preservation of social peace). Finally, this paper provides an overview of climate change by country, scenario analysis, and policy recommendations.
\end{abstract}

Keywords: Climate change, Western Balkans, European Union, European Green Deal

*Correspondence: snezana.strbac@ihtm.bg.ac.rs

${ }^{2}$ Institute of Chemistry, Technology and Metallurgy, University of Belgrade, 11000 Belgrade, Republic of Serbia

Full list of author information is available at the end of the article

\section{Background}

The atmosphere is warming and the climate is changing every year. One million of the eight million species on the planet are at risk of extinction. Forests and oceans are polluted and destroyed [1-4]. Over the last 20 years, governments have intensified their consideration of the threats posed by climate change, by gradually implementing strategic action measures to combat such original author(s) and the source, provide a link to the Creative Commons licence, and indicate if changes were made. The images or other third party material in this article are included in the article's Creative Commons licence, unless indicated otherwise in a credit line to the material. If material is not included in the article's Creative Commons licence and your intended use is not permitted by statutory regulation or exceeds the permitted use, you will need to obtain permission directly from the copyright holder. To view a copy of this licence, visit http://creativecommons.org/licenses/by/4.0/. The Creative Commons Public Domain Dedication waiver (http://creativeco mmons.org/publicdomain/zero/1.0/) applies to the data made available in this article, unless otherwise stated in a credit line to the data. 
change, and in parallel, by advancing scientific knowledge on climate change. So far, the global policy response has mainly focused on mitigating climate change by reducing anthropogenic emissions of greenhouse gases (GHG).

The European Commission (EC) officially adopted the European Union (EU) strategy on adaptation to climate change in 2021. The Strategy sets out how the EU can adapt to the unavoidable impacts of climate change and become climate neutral by 2050 . In addition to the Strategy, European Green Deal (2019) is also a response to these challenges [5]. The European Green Deal is part of the strategy of the EC for the implementation of the United Nation's 2030 Agenda and the Sustainable Development Goals (SDGs) [6], and aims to transform the EU into a prosperous society, with a modern, resource-efficient, and competitive economy, which has no net GHG emissions in 2050 and where economic growth is separate from resource use. It also aims to protect, preserve and enhance the EU's natural capital, and to protect the citizen's health and well-being from the risks and impacts associated with changes in the environment. The EC has proposed a new (8th) Environmental Action Programsupporting the European Green Deal and includes new monitoring mechanisms to ensure that Europe stays on track to meet its environmental goals. The EU must lead international coordination to build a coherent financial system that supports sustainable solutions. The EU and its member states have become broadly committed to adaptation to climate change, and have begun to address these challenges by establishing adaptation strategies at all levels. The most important of these are the national energy and climate plans and the proposed strategic national plans for the implementation of the common agricultural policy. The EC has encouraged all member states to develop adaptation strategies in line with national plans to reduce the risk of climate change, including cross-border issues. It also supports the efforts of European cities to prepare local adaptation strategies and plans. Local adaptation strategies and plans will increase support for local activities, providing a platform for greater engagement and networking of municipalities, and raising public awareness of adaptation to climate change. To address the adjustment of the most vulnerable sectors, the EC continues to integrate adaptation into EU policies. The EC also seeks to improve the resilience of infrastructure to climate change in Europe through a review of existing standards in the fields of energy, transport, and construction. Member states must also ensure the effective implementation of all policies and laws.

Climate change does not know borders, contributing to the fast deterioration of the environment. An effective approach to face climate change challenges is through cross-border cooperation. Cross-border cooperation could be the catalyst to stop the ecosystem degradation and develop the basis for a more sustainable development paradigm [7]. The environmental ambitions of the European Green Deal will not be achieved by acting only within the boundaries EU. The EU must use its influence, expertise, and financial resources to mobilize its neighbors to join them on a sustainable path. Furthermore, the transferability of knowledge on climate change adaptation in European and neighboring countries is considered crucial in the early stages of planning and implementing concrete measures.

From that aspect, the Western Balkans is a particularly interesting area for the EU. The main objective of this paper is to answer the following questions: (i) is climate change observed in Western Balkans? (ii) How are certain sectors vulnerable to climate change in Western Balkans? (iii) What are the climate change adaptation strategies in the six countries of the Western Balkans? The answers to these questions can help in planning activities and initial alignment of Western Balkan countries with the EU plan to achieve net zero greenhouse gas (GHG) emissions by 2050. The working hypothesis of this paper reads: the Western Balkans can play an important role in maximizing the impact of the European Green Deal.

The Western Balkans is a term used by the EU for a region that includes Bosnia and Herzegovina, the Republic of North Macedonia, Montenegro, Republic of Serbia, Croatia, and Albania (Fig. 1). Most countries of the Western Balkans (Bosnia and Herzegovina, Republic of North Macedonia, Montenegro, Republic of Serbia, and Croatia) spent the 1990s affected by the conflict over the break-up of the Socialist Federal Republic of Yugoslavia, which delayed economic transition and resulted in significantly lower living standards than EU countries [8].

Now, as the Republic of Serbia, Bosnia, and Herzegovina, the Republic of North Macedonia, Albania, and Montenegro strive for stability, they face the challenges brought by climate change and do so with limited budgets for addressing issues of environmental protection, insufficient environmental regulation or implementation, limited public participation, and political tensions [10]. The main goals of the countries in the region are EU integration and $\mathrm{EU}$ accession, with the fact that is Croatia becoming a member in 2013 [8]. As potential candidates and candidates for EU accession, all countries are motivated to respect the Paris Agreement and achieve the EU2020 and EU2030 goals of increasing energy efficiency, reducing GHG emissions, and producing energy from renewable sources. The EU integration will have a strong impact on climate and environmental policies, laws, and actions in the coming decades [11].

In this paper, the data were obtained through desk research of the secondary literature (relevant 


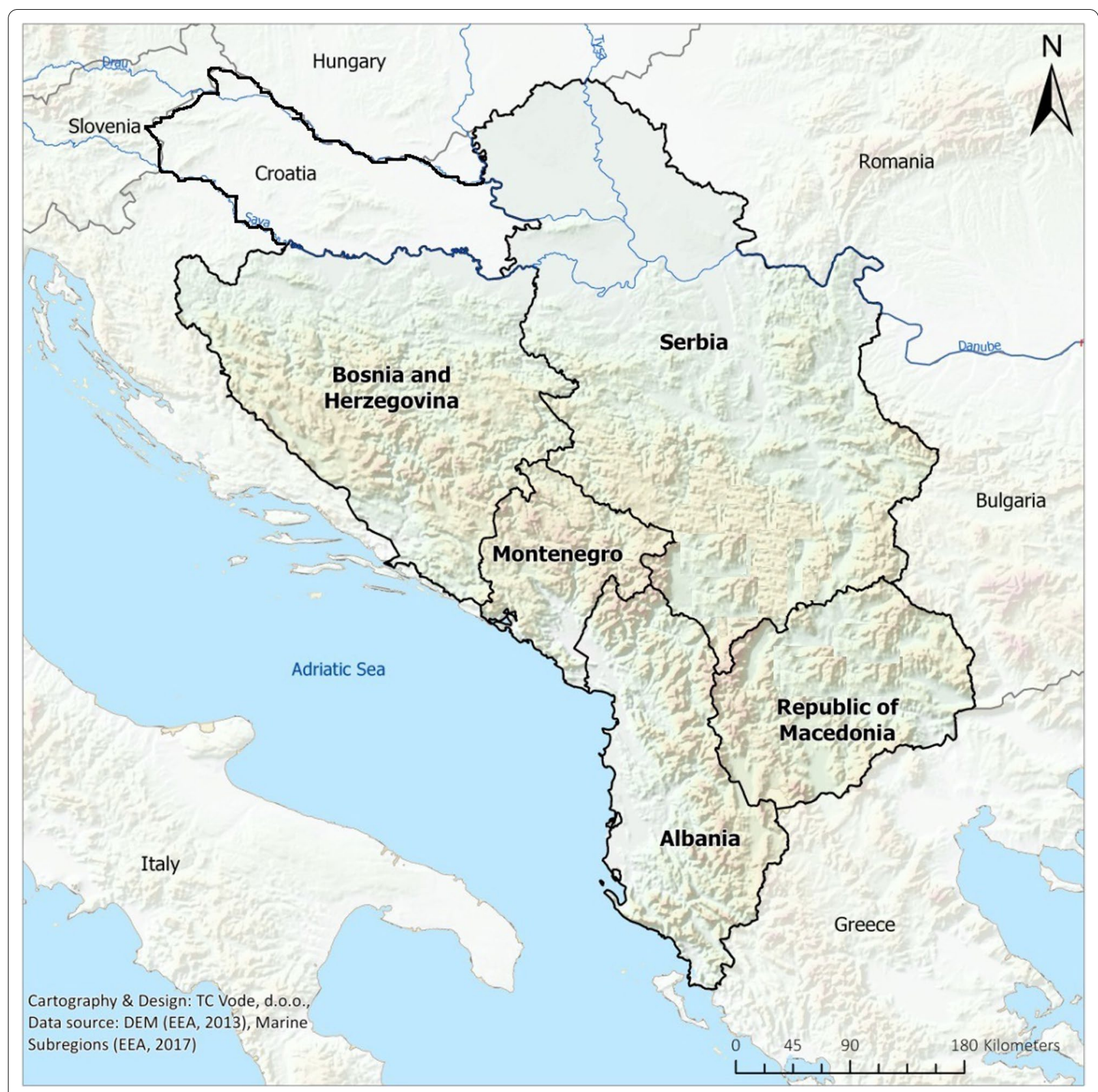

Fig. 1 Western Balkans countries [9]

publications, articles, relevant state documents, etc.) of the Western Balkan countries. Variable data were used as relevant data indicating the existing climate change in the Western Balkans. Desk research will identify: (i) key factors affecting climate change in Western Balkans, (ii) the vulnerability of individual sectors to climate change, and (iii) climate change adaptation strategies. All these will help to determine the state of climate change in six Western Balkan countries to plan activities and initial harmonization with the EU to reach net-zero GHG emissions by 2050 .

\section{Main indicators of climate change climate change in the Western Balkans}

In proportion to the size of its geographical area, the Balkan countries are characterized by a different climate. Albania has a Mediterranean climate with humid, mild winters and dry, warm summers, as well as the southern 
part of Montenegro and the coastal and lowland areas of Bosnia and Herzegovina. In the remaining areas of Bosnia and Herzegovina, the climate ranges from moderately continental to alpine. The central and northern parts of Montenegro have the characteristics of a mountain climate, the far north of Montenegro has a continental climate, but with the influences of the Mediterranean Sea on temperature and precipitation. Most of Croatia has a rainy-moderately warm climate. The climate in Republic of North Macedonia varies from sub-Mediterranean to moderately continental/sub-Mediterranean to continental and from cold-continental to alpine sub-climate. Republic of Serbia's climate varies in most areas from moderately continental to continental in the mountains to Mediterranean subtropical and continental in the southwest [12]. To assess the impact of global warming on climate change across the Western Balkans region, two meteorological parameters were selected: temperature and precipitation.

\section{Temperature}

The temperature in the region has risen in the last 50 years and every country has experienced warming with the acceleration of this trend in recent decades [12]. The average temperature increased by $1.2{ }^{\circ} \mathrm{C}$. The temperature increases from south to north. Through central and southern Albania and North Macedonia, changes are in the interval of $0.5^{\circ} \mathrm{C}$ to $1.0^{\circ} \mathrm{C}$, and over northern Albania and other Western Balkan countries in the interval $1.0-1.5^{\circ} \mathrm{C}$. The average 10 -year trend has a similar spatial distribution of change intensity, with values of $0.15{ }^{\circ} \mathrm{C}$ to $0.2{ }^{\circ} \mathrm{C}$, declining to the south, and mostly increasing in the central part of the region [11]. Temperature changes can be analyzed seasonally in winter (December-January-February), spring (March-April-May), summer (June-July-August), and autumn (September-October-November). Undoubtedly, the highest increase in temperature is during the summer season [11]. Summer is the season for which scenarios and trends with the highest temperature increases are predicted [13]. The frequency of extreme temperatures (heat waves) has also increased across the region [8].

According to the Two Representative Concentration Pathways (RCP), two future climate change scenarios are foreseen for the Western Balkans region: RCP4.5 (stabilization scenario, with the peak of GHG emissions around 2040, and their decline thereafter) and RCP8.5 (a scenario of continuous increase, where GHG concentrations continue to rise until the end of the century). According to the RCP4.5 scenario, the expected temperature changes over the near future (2016-2035) are with an average increase of $0.8{ }^{\circ} \mathrm{C}$, and according to the RCP8.5 scenario, temperature changes are significant with an average regional increase of $1.0{ }^{\circ} \mathrm{C}$. The expected temperature changes according to the RCP4.5 scenario during the end of the century (2081-2100) are that the temperature increase shows stabilization with an average increase of $2.0^{\circ} \mathrm{C}$, and according to the RCP8.5 scenario, the temperature will continue to rise significantly, reaching an average value of $4.4{ }^{\circ} \mathrm{C}$. During the end of the century (2081-2100) according to the RCP4.5 scenario, the temperature stabilizes, and according to the RCP8.5, frost days (over 50 days) are expected to decrease in the entire region [11]. The medium-emission scenario predicts that the eastern Mediterranean will be warmer by the end of the twenty-first century of $3.5-7^{\circ} \mathrm{C}$, with the largest daily increase recorded in the Western Balkans [14]. Based on the high emission scenario, a warm-up of $5-8{ }^{\circ} \mathrm{C}$ will be in the eastern Mediterranean in summer [15]. Among the existing models, the consensus is that during the twentyfirst century, the Western Balkans will experience significant warming [8], which will be higher than the world average [16]. Based on climate change projections, climate change can be expected to continue in the Western Balkan region in the future [17].

\section{Precipitation}

In the last 50 years, changes in precipitation have not been as clear as changes in temperature. Due to the complex topography of the mountains, generalizing the observed climate trends is difficult, especially since the Western Balkans have two climatic areascontinental/Mediterranean and alpine [8]. The average annual accumulation of precipitation in the Western Balkans region did not change compared to the period from 1961 to 1980 . The current change in precipitation is $0.2 \%$. During the $1980 \mathrm{~s}$ and $1990 \mathrm{~s}$, the amount of precipitation decreased, only to then begin to increase and return to values from the period defined as the past climate (1961-1980). This is the reason for the small change of $0.2 \%$ [11]. The Western Balkans will witness a significant reduction in annual rainfall. Two scenarios, RCP4.5 and RCP8.5, can also be chosen for future precipitation predictions. According to the scenario RCP4.5 during the near future period (2016-2035) compared to the base period (1986-2005), the amount of precipitation will not have significant expected changes in either annual or seasonal values, the mean annual change will be within the interval $-5 \%$ and $+5 \%$. According to the RCP8.5 scenario, the change in precipitation shows a similar trend as in the RCP4.5 scenario, but with a slightly different distribution. During the middle ages (2046-2065) according to scenario RCP4.5, the expected changes in precipitation will not show statistically significant changes in average annual and seasonal values, and according 
to scenario RCP8.5, the decrease in precipitation will be significant in Albania and part of Montenegro during June-July-August. During the end of the century (2081-2100) according to the RCP4.5 scenario, the expected changes in the amount of precipitation will be stabilized, and according to the RCP8.5 scenario, a serious decrease in the amount of precipitation will be during the June-July-August season in southern Bosnia and Herzegovina, Montenegro, Albania and the Republic of North Macedonia [11]. In high-emission scenarios, the expected decrease in precipitation is especially pronounced in summer [15]. In winter, on the contrary, the amount of precipitation will increase in the mountains and the region in general $[18,19]$. Extreme rainfall is not expected in the region; however, floods are predicted to become more frequent due to more winter rainfall that will cause spring floods [20].

\section{GHG emissions and mitigation}

From 1990 to 2018, $\mathrm{CO}_{2}$ emissions for the Western Balkans ranged from 1 to just over 8 metric tons per capita (Fig. 2). Annual emissions per capita are slightly more than half of the emissions for EU countries, and slightly more than a quarter compared to the United States (Fig. 3) [12]. The largest discrepancy is evident in the data on total emissions. Compared to China, the US, and the EU, emissions from the Western Balkans are barely registered (Fig. 3) [12].

From 1990 to 2018, total GHG emissions (kt of $\mathrm{CO}_{2}$ equivalent) for the Western Balkans are presented in Fig. 4.

Greenhouse gas emissions in Albania between 1990 and 2000, associated with changes in land use and forestry, declined significantly, while emissions in all other sectors increased. Total emissions related to land-use change and forestry accounted for $45 \%$ of total emissions. The increase in emissions in the energy sector combined with the decrease in emissions related to changes in land use and forestry has resulted in the energy sector having the largest share in total emissions in Albania. The waste sector shows the largest percentage increase, but in absolute terms, waste emissions have increased less than in any other sector [12]. Data on GHG emissions for Bosnia and Herzegovina for individual sectors are only available for 1 year, so trend analysis is not possible [12]. In Croatia, in the period from 1990 to 2007, the energy sector accounted for $70 \%$ of total GHG emissions. During that period, emissions in the waste, transport, and energy sectors also increased, while in the agricultural and industrial processes sectors, emissions decreased. Thanks to changes in land use and forestry, the absorption of GHG emissions has increased, which have further reduced total emissions [12]. In the Republic of North Macedonia between 1990 and 2002, the reduction in emissions

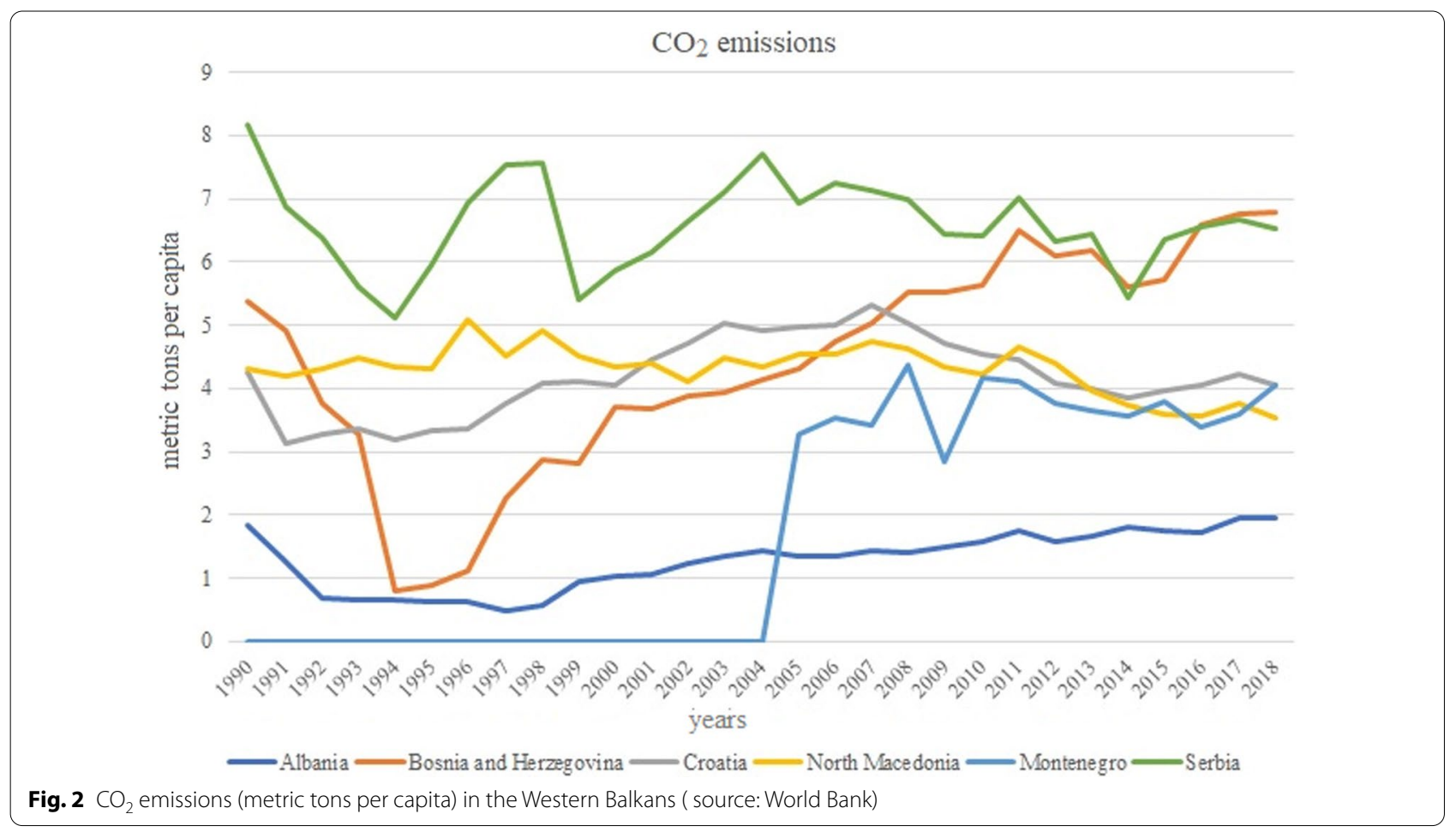




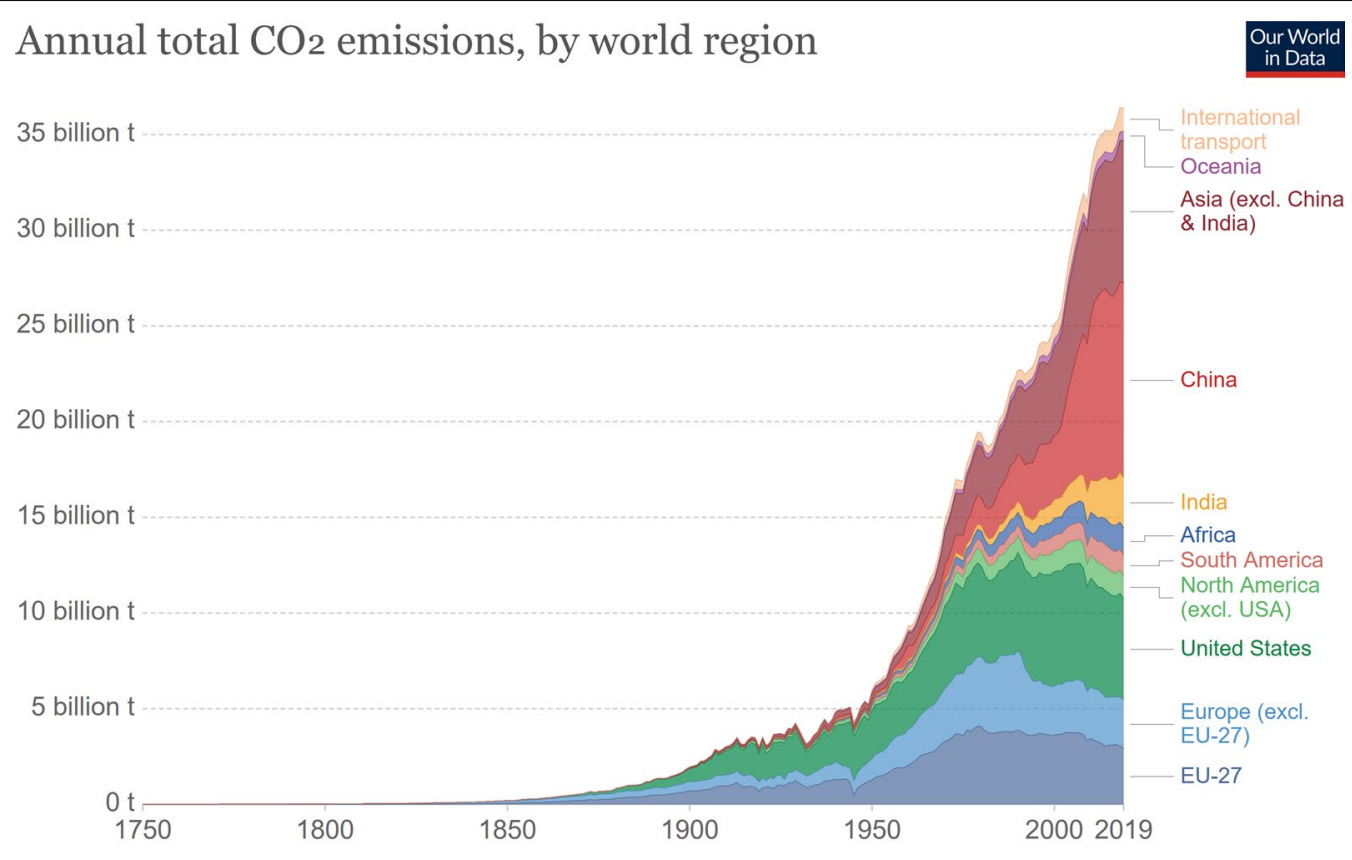

Source: Our World in Data based on the Global Carbon Project $\quad$ OurWorldlnData.org/co2-and-other-greenhouse-gas-emissions • CC BY Note: This measures $\mathrm{CO}_{2}$ emissions from fossil fuels and cement production only - land use change is not included. 'Statistical differences' (included in the GCP dataset) are not included here.

Fig. 3 Annual total $\mathrm{CO}_{2}$ emissions, by world region ( source: World Bank)

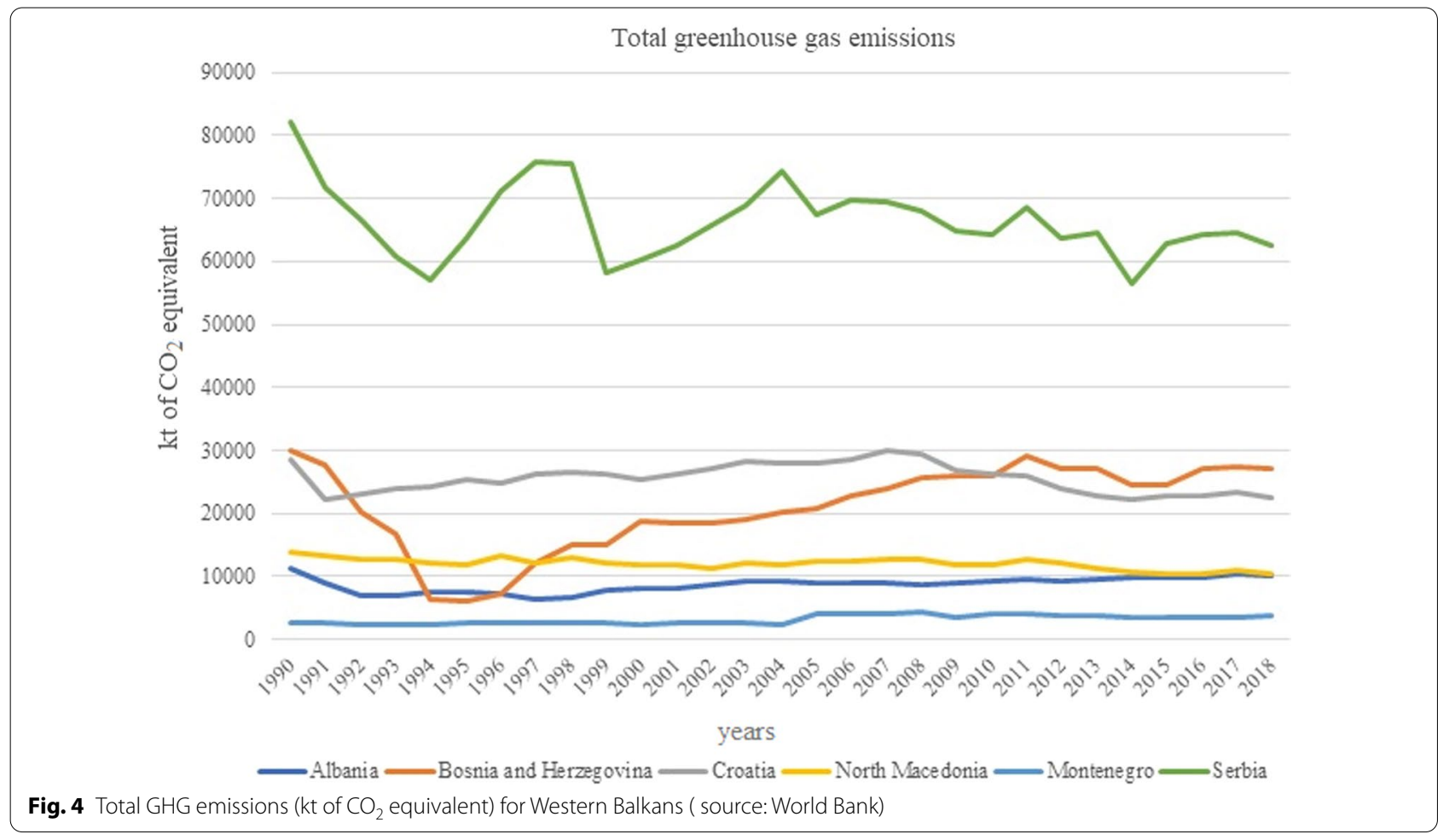


related to land-use change and forestry seems impressive, but this sector accounts for only $2 \%$ of total emissions. In 2002, the energy sector accounted for the largest share of $70 \%$. In that period, total GHG emissions fell by $8 \%$, which can be mainly attributed to the reduction of emissions from the agricultural sector [12]. In Montenegro, total GHG emissions decreased by $2 \%$ between 1990 and 2003, with changes in land use and forestry making the largest contribution. However, in 2003, the sector accounted for only $17 \%$ of total emissions. Although emissions from the energy sector increased during this period, the share of total emissions attributed to the energy sector increased by 3\% [12]. Between 1990 and 1998, GHG emissions in the Republic of Serbia decreased by $22 \%$, with this decrease comes from the energy sector (79\%). Emissions related to land-use change in both the forestry and waste sectors have experienced a significant percentage change, but these sectors represent a small percentage of total emissions [12].

\section{Vulnerability of individual sectors to climate change}

In terms of the amount of water available per person, the countries of the Western Balkan are the richest in water in Europe (10,600 cubic meters, which is twice the European average) [21]. Most of the water from this area derives from mountain springs, while in some countries a significant part of the water derives from transboundary rivers. Water resources have always played an important role in the economy of the Western Balkan. Agriculture as one of the most important sectors largely depends on water. Disturbances in the precipitation regime, higher risks of drought, and extreme weather conditions have significant implications for the stability of this sector. In addition to agriculture, water resources are also used to produce electricity. In the Western Balkans, about 37\% of electricity produced comes from hydropower [8]. In some countries, this percentage is much higher: Albania (100\%), Montenegro (45.3\%), and Croatia (42\%) [8]. In 2018, 70 percent of renewable energy support in the Western Balkans benefited small hydropower. Between 2009 and the end of 2018, at least 380 small hydropower plants were built in the region. Small hydropower's contribution to electricity generation is extremely modest, only $3.6 \%$ of electricity in the Western Balkans in 2018 was generated by hydropower plants under $10 \mathrm{MW}$. Perceived corruption and nepotism in the renewables incentives system endangers public acceptance of the whole transition to an energy-efficient, renewablesbased energy system. It urgently needs to be addressed by switching to a more transparent renewables support system, in line with the EU's Guidelines on State Aid for Environmental Protection and Energy [22]. Accelerated evaporation and drought, as well as changes in water regime have important implications for this sector. More frequent extreme events, such as floods, can also threaten energy infrastructure. In terms of water resources, the region faces several common problems, including weak transboundary cooperation and water pollution. After the break-up of the former Yugoslavia, there are more than 13 internationally common basins and four crossborder lakes. Most states share one or more basins. Cross-border cooperation is generally weak, with poor information exchange and joint monitoring, insufficient institutional capacity, and low political priorities [23]. One of the main reasons for concern is water quality. The main source of surface and groundwater pollution is wastewater discharge. Wastewater treatment is often poor or completely absent [24]. In many Western Balkan countries, groundwater sources are at risk of agricultural runoff pollution-the biggest impact of nitrogen pollution [21]. Climate change poses additional challenges in terms of water quality, availability, and management. Climate change will pose a significant risk to sectors, where water is a limiting factor, and will also exacerbate existing pressures on water resources. Countries in the region according to almost all climate projections will experience a significant drop in precipitation followed by increasing drought conditions and thus reducing water availability [25]. Higher temperatures will also move the snow line. By 2050, the snow cover is expected to decrease [26]. Intense precipitation and increased snowmelt during the winter will increase the risk of floods across the region [16].

Land quality has broad implications for both agriculture and the productive capacity of the land. The risk of land degradation will increase with climate change. Rising temperature, changing precipitation patterns, floods and droughts directly affect soil properties and processes, which can lead to accelerated erosion, soil degradation, and desertification [27]. When drought is followed by periods of intense rain on steep, unstable terrain, the land is unable to absorb large amounts of water, resulting in excessive runoff, landslides, and floods. Fires and overexploitation of resources can further contribute to desertification [27]. Desertification leads to the loss of the proper hydrologic soil function, biological productivity, and other ecosystem services as a result of human activities and climate change. All countries in the region have extremely diverse natural potential for agricultural production, from fertile plains and river valleys to less productive karts, hilly and mountainous areas. The agricultural sector in the region accomplishes an average of $11 \%$ of gross domestic products (GDP) [28]. Eighteen percent of the population is employed in agriculture [29], which is often an economic and development driver for 
rural areas, where the share of employees in agriculture is much higher than the national average. Agriculture is a sector that can be considered the most vulnerable to climate change. Droughts in the Balkans have been identified as a key risk for agricultural production [30]. Future projections of climate change and their impact on agriculture at the European level indicate that there will be more losses in the southern areas, including the Balkans. Key risks include reduced and increased yield variability, as well as reduced areas suitable for growing traditional crops [31]. The negative effects of climate change on yields could be reduced if adaptation options were applied, but this would require $40 \%$ more water [32]. Some alpine-mountainous regions, which today are characterized by lower average temperatures, may benefit. For example, wheat yields in alpine areas are projected to increase significantly [33]. The livestock sector is currently underrepresented in climate impact research in the region and there are only a few modeling studies [16].

Forests cover a large part of the land area of the Western Balkans [29] and play a significant economic and social role in all countries, both in terms of national economies and in terms of livelihoods. The wood industry significantly contributes to the development of local economies. In some countries, the contribution of forestry to GDP is high, such as in Montenegro (8\%), while in other countries it ranges between 0.5 and 2.5\% [34]. Forests also provide several ecosystem services, including maintaining biodiversity, mitigating and adapting to the effects of climate change, and regulating soil and water regimes. The mountainous areas of the Western Balkans covered with forests are very rich in biodiversity, both in terms of flora and fauna, whether of global or European importance for conservation [8]. There are vast areas of preserved, natural, and semi-natural ecosystems that benefit both nature and humans through ecosystem services. Most local communities still depend heavily on them. Rainforest relics still exist in remote areas, mountains, and swamps, representing the last refuge of these biotopes in Europe [35]. The reduction of the rural population and migration from rural to urban areas, especially from mountainous areas, has resulted in fewer and fewer young people engaging in forestry and exerting less pressure on cutting firewood for households. However, there are still concerns in the region about the quality of forests due to inadequate management of state-owned and privately owned forests [34], while factors such as illegal logging and corruption hinder the forestry sector from reaching its full potential. Climate change is also a risk to forests and their management. A significant increase in the number and intensity of forest fires across the region is associated with higher summer temperatures, prolonged droughts, and earlier melting of snow on the mountains [36]. In the future, the probability of an increase in forest fires, the length of the fire season, the frequency and intensity of fires will increase in the Mediterranean [37]. Furthermore, the increase in $\mathrm{CO}_{2}$ concentration in the atmosphere, higher temperatures, changes in precipitation, floods, and the duration and frequency of drought will have significant effects on tree growth. These changes will have consequences on the frequency of pest and disease outbreaks [8].

The Western Balkans is a hotspot of biodiversity in Europe and contains a great diversity of ecosystems. The territory of the former Yugoslavia is one of the six European centers of biodiversity, containing $40 \%$ of vascular plants in Europe, $51 \%$ of fish, $74 \%$ of birds, and $68 \%$ of mammals [12]. There is a high level of endemism in the Balkan countries due to the extremely diverse geology, soil, climatic ranges, and altitude. The number and size of protected areas in the region are increasing, although the share of protected land is still low compared to the share in the EU. EU Biodiversity Strategy to 2030, as part of the European Green Deal, is a comprehensive plan for protecting nature and reversing the degradation of ecosystems. The Strategy is set to establish protected areas for at least 30\% of both land and sea in Europe, restore degraded ecosystems and unlock 20 billion EUR/year for biodiversity through various sources, including EU funds, national and private funding [38]. Biodiversity in the region faces several threats, including deforestation, soil erosion, uncontrolled land use and pollution, as well as unsustainable hunting, fishing, and grazing [8]. Climate change is expected to affect all ecosystems in the region, but ecosystems with limited species migration opportunities are particularly at risk. Large reductions in snow cover will lead to a decrease in alpine flora and fauna, as the vegetation of the foothill regions will be replaced by the vegetation of temperate zones [8].

In the Western Balkans region, achieving efficient and modern internal transport networks and infrastructure and communication networks between the countries of the region will be a key driver of economic growth and transition. Today's challenge is to maintain the integrity and increase the capacity of infrastructure to meet changing demand-economically, environmentally friendly, safely and within the tight fiscal and policy schedules required. This is a political priority of the countries themselves and the EU, because it is an important tool for improving ties across the region and the integration of neighboring countries into the political and economic flows of Europe [8]. A series of infrastructure projects are planned, including funding from the Instrument for PreAccession Assistance (IPA), which will connect capitals, major cities, and airports in the region, enabling faster economic progress by 2030. Most of the Western Balkans 
transportation infrastructure was built in the 1960s and 1970s and is, therefore, is in urgent need of rehabilitation or replacement. Although the transport system of the Western Balkan countries has improved over the years, the standards are significantly lower than European ones. Road congestion in and around cities, aging vehicles, poor vehicle maintenance, and changing road conditions all contribute to poor air quality. Pressure on road networks has also increased, between 2001 and 2006 freight transport has almost doubled, and public transport within and between cities is considered inadequate [12]. Transport accounts for almost a quarter of the world's $\mathrm{CO}_{2}$ emissions. Although this figure is lower for the Western Balkans region, at approximately 14\%, the share of emissions in the transport sector is growing in line with socio-economic developments. Despite all the benefits that air transport provides, airplanes are also large emitters of GHG and contribute significantly to climate change. The number of emissions that occur during one continental flight in Europe is many times higher than the use of other means of transport. At the moment, the aviation industry is responsible for about $2 \%$ of total global emissions, and although there are initiatives and measures to reduce them, it is the sector in which emissions are currently growing the fastest. An even bigger problem is the fact that the emissions of international aviation are increasing from year to year; currently, the emissions are $70 \%$ higher on an annual level compared to 2005. It is predicted that, if measures are not introduced to reduce emissions, emissions will increase by an additional $300 \%$ by 2050 . There are no available studies on GHG emissions resulting from air traffic in the region, but they are certainly significant, as the Balkan region is a transit route for a large number of flights. An additional problem is the relatively old airport infrastructure, air pollution, as well as the lack of key competencies of staff engaged in the air transport sector, as well as related companies [39]. Air transport must be transformed into a zero-emission sector. There are few studies on the effects of climate change on transport networks in the region [8]. As identified by the World Bank Report of Natural Disaster Hotspots: A Global Risk Analysis, the Western Balkans is particularly susceptible to earthquakes, hydrological hazards (droughts and floods), and wildfires in forest regions. As climate change continues to alter the frequency and intensity of many types of events, these acute shocks can be expected to worsen in the future [40]. For road infrastructure, time stress already represents 30 to $50 \%$ of the current cost of road maintenance in Europe. Ten percent of these costs ( 0.9 billion Euros) are related to extreme events, and floods are taking the lead. Significant additional costs for road transport infrastructure are projected due to more frequent extreme rainfall and floods (50-192 million Euros per year between 2040 and 2100). Climate change in combination with transport has a strong impact on air quality. Emissions from transport contribute to air pollution and GHG that cause climate change; whose effects-especially higher temperaturesworsen human health reactions to air pollution. An efficient transport sector would reduce GHG emissions and reduce the health effects of air pollution.

The region has a long history of mining. Exploitation includes aluminum, chromium, cobalt, copper, iron, lead, magnesium, manganese, nickel, and zinc, and from precious metals gold, palladium, and platinum, and lignite, natural gas, and oil [12]. By the 1990s, mining, mineral processing, and exploitation had established the region as a major European source of copper, lead, and zinc, and the mining industry was one of the leading industrial sectors [8]. After the collapse of the common Yugoslav market in the 1990s, industrial production declined significantly, resulting in reduced pollution, but also many abandoned mines scattered throughout the region. Within the region, approximately one-third of the 180 sites identified are considered significant environmental issues, and one-fifth pose cross-border risks. Environmental problems include waste generation, air pollution, adverse effects on land and biodiversity, water pollution, hazardous substances, noise and vibration, and visual/ aesthetic impacts [8]. The dominant routes of exposure to pollutants are rivers, which poses a critical transboundary pollution risk for countries in the region. Climate change may exacerbate the above-mentioned existing environmental problems. The risk is increased by a combination of natural disasters, such as floods (as a result of more intense precipitation expected in the winter and spring months) and poor infrastructure.

The Western Balkans have huge potential for sustainable tourism due to its rich cultural heritage and diversity, attractive coastlines, and historic cities. Tourism is one of the largest and fastest-growing economic sectors in the region, and most countries are expected to grow significantly in terms of both contributing to GDP and creating jobs. Similar to agriculture, tourism depends on natural conditions, especially in coastal and mountainous regions. Climate change is projected to have a significant impact on the sensitive mountain environment, with implications on tourism and the occurrence of natural hazards [8]. Mountain ski resorts are among the tourist sectors that are considered to be the most endangered, because it is expected that the duration of the snow season will be significantly reduced in the future. The concentration of activity on a smaller area and in a shorter period during the year could also put more pressure on sensitive mountain ecosystems. Coastal regions are also considered very sensitive to climatic conditions, and the 
Mediterranean region as a whole is expected to become less attractive due to drought and higher temperatures. On the other hand, higher temperatures in the coastal region may favor tourism in hilly and mountainous areas. There are other broad, potential indirect impacts of climate on tourism in the region, such as changes in freshwater quality, changes, and losses in biodiversity, changed agricultural production-wine tourism, landslides and forest fires, higher incidence of vector diseases. Mitigation policies aimed at reducing GHG emissions will increase transport costs and may have an impact on tourists' travel patterns. In the region, the tourism will undoubtedly continue to be a growing sector regardless of the climate change challenges.

For the economic development of the Western Balkan countries, the energy sector is considered very important [41]. The main sources of electricity production in the region are lignite and hydropower. To generate the electricity Republic of Serbia, the Republic of North Macedonia, and Bosnia and Herzegovina are mainly dependent on lignite (coal) thermal power plants. Almost all its electricity Albania draws from hydropower, while Bosnia and Herzegovina, Croatia, and Montenegro also have significant hydropower capacity [8]. Due to the high dependence and use of coal (lignite), the region as a whole has a high percentage of carbon emissions, so that the current patterns of energy use in the Western Balkans lead to a significant impact on the environment (e.g., indoor and local air pollution from inefficient and improperly used stoves, deforestation and land degradation. The energy sector in the region is the main source of pollutants, and GHG emissions. The energy intensity (energy efficiency indicator) of the Western Balkans is high. This can be attributed to the degraded state of energy infrastructure, large energy losses during transformation, transmission, and distribution, and inefficiencies in the end-use sector. In addition, high dependence on imported energy (oil and natural gas) raises concerns about the security of energy supply and the need to diversify new sources (renewable sources: biomass, solar, and wind energy), as well as the introduction of energy efficiency.

Energy systems in the region are considered to be very sensitive to extreme events and temperature changes $[16,42]$. The extent and nature of the impact depend on the degree to which countries rely on different energy sources. Thermal energy production is sensitive to climate change due to the high dependence of power plants on cooling water $[43,44]$. Lower levels in lakes and rivers, reduced runoff, accelerated evaporation, and warmer water can cause restrictions on cooling water intake or discharge, limiting production capacity [45]. Taking into account the effects of climate change on river water temperature and river flows, the capacity of nuclear and fossil fuel power plants in Southern and Eastern Europe could face a decline of $6-19 \%$ for the period $2031-2060 \mathrm{com}$ pared to the period from 1971 to 2000 [45]. More frequent extreme events, such as floods, will also jeopardize all types of energy infrastructure and lead to increased maintenance costs [12]. In the Western Balkans, much of the energy infrastructure requires extensive rehabilitation and replacement, given that it was built in the $1960 \mathrm{~s}$ and 1970s [8]. Climate change is expected to pose risks to electricity transmission network functioning and reduce efficiency especially for older, poorly maintained facilities [12]. Following the expected decline in annual river water levels and the changing seasonality of river flows, total hydropower production in Europe, including the Western Balkans, is expected to fall by $1.66 \mathrm{TWh}$, or $1.43 \%$, compared to 2005 production levels [45]. On the demand side, the trend of warmer winter temperatures and even warmer summers is expected to align the electricity consumption profile, as the demand for cooling energy increases and the thermal energy decreases [12]. Electricity systems can be burdened to meet more stringent air conditioning requirements, especially if they rely on hydropower [45]. Energy consumption in the Western Balkans has already increased by 53\% between 1995 and 2005, and demand is expected to grow by an additional $34 \%$ from 2006 to 2030 [27]. Economic development, population growth and climate impacts (reduced production and interruptions in electricity production) can together contribute to rising electricity prices and the risk of electricity shortages in the region [45-47].

\section{Future challenges}

\section{Adaptation to climate change}

Adaptation is a risk management strategy that intends to respond to the inevitable effects of climate change and increase resilience-the ability to respond to a change in function or condition in the environment by resisting damage and recovering quickly. The countries of the Western Balkans face several challenges in terms of their adaptability. Countries with well-established, efficient governance and strong, stable economies have a distinct advantage in their adaptable capacities. Croatia has the largest adaptive capacity, the Republic of North Macedonia has the lowest adaptive capacity, while Albania, Bosnia and Herzegovina, and the Republic of Serbia are in the middle [12]. There is not enough data for Montenegro.

In Albania, hydropower sources produce more than $95 \%$ of the country's electricity. The share of total demand for renewable energy including hydropower fell from $42 \%$ in 2000 to $22 \%$ in 2007 . The expected increase in long-term mean annual and seasonal air temperatures in Albania and a decrease in mean annual and seasonal 
rainfall will reduce long-term mean annual and seasonal water runoff. It is predicted that a $20 \%$ reduction in runoff will cause a $60 \%$ reduction in production. This means that while hydropower may be good for reducing GHG emissions, relying on hydropower can increase a country's vulnerability to climate change. The precipitation regime is also important for agriculture, which is still the backbone of the Albanian economy. In the transition from the communist rule to multi-party democracy, Albania has undergone major political, institutional, and socio-economic changes, and governments have struggled with high unemployment, widespread corruption, poor infrastructure, and powerful organized crime networks, all in a disputed political environment. The transition from a centrally planned state to a more modern open-market economy has been difficult, but the government has adopted a package of fiscal reforms aimed at reducing the large gray economy and attracting foreign investment [12].

With regard to water resources in Croatia, there is growing concern about whether water supplies can meet the growing needs for drinking water. The main issues in agriculture relate to water availability and elevated temperature and focus on the prospects of reduced water supply and a higher frequency of droughts. Although Croatia has largely achieved macroeconomic stabilization, deep public resistance and weak political support have inhibited structural reforms. The long-term outlook for growth remains strong, but difficult problemshigh unemployment, growing trade deficits, and uneven regional development-remain. The global financial crisis will create significant pressure, and Croatia's high external debt weakened the export sector, tight state budget, and excessive reliance on tourism revenues will result in a greater risk to economic stability in the medium term.

In the Republic of North Macedonia industry and agriculture are the two most important sectors of the economy, but the services sector has recently gained much importance. Agriculture is a priority sector that makes up a significant part of GDP, thus contributing to social security and poverty reduction. The Republic of North Macedonia will expect very different effects from changes in temperature and precipitation: projections for reducing effective rains vary from 15 to $40 \%$. Of the country's available water resources, $84 \%$ is formed within its borders, so the country is particularly sensitive to the overall reduction of effective rainfall. Agriculture will bear the greatest burden of negative consequences, and the greatest effects are expected in the central and southeastern parts of the country. The Republic of North Macedonia has limitations at the systemic, institutional, and individual levels. Lack of resources and staff is evident in the ministries of environment and spatial planning, economy, transport, health, and industry. The main economic problems of the Republic of North Macedonia are low living standards, high unemployment, and relatively modest economic growth [12].

Montenegro's vulnerability to climate change is greatest for forest ecosystems. Most Montenegrin forests are established by natural regeneration, and due to their climate and terrain, they are characterized by high biodiversity. They are important producers of biomass and are sources of fruits, herbs, and mushrooms. They represent habitats for wild plant and animal species; they maintain and regulate the hydrological regime; protect against landslides and erosion, and absorb significant amounts of carbon. The extremely diverse ecosystems of Montenegro are characterized by rich flora and fauna-about 3,250 plant species, with the highest ratio of vascular flora and surface in Europe. Of the 526 European bird species, 297 can be found regularly in Montenegro, while about 29 other species are occasionally present. The country's small national economy was hit by the 2009 recession, which was significantly caused by negative global economic trends. Unemployment and regional disparities in development remain key political and economic problems [12].

Bosnia and Herzegovina is very susceptible to the impacts of climate change given its limited capacity for adaptation. Financial constraints and limited institutional capacity have limited adaptation capabilities and effective response to climate hazards. It is necessary to improve research and extension services to enhance the capacity and delivery of information to the agricultural sector, with particular reference to climate change and the implementation of adaptation options. Improved management of water resources at the watershed level could help address potential challenges in the hydropower sector due to river discharge. Additional development of hydropower plants could be a promising source of renewable energy in a long-term adaptation strategy. It is necessary to improve the capacity of energy systems to sustain cumulative impacts, such as: the redundancy at peak periods, the sensitivity of regulators to climate change pressures on infrastructure, and demand management and energy conservation strategies. Adaptation approaches for Bosnia and Herzegovina's water sector are currently limited by a lack of reliable data. Investment needs to be made to support structural adaptation changes in the country's water management structure, in particular to support agriculture and energy sectors. Adaptation strategies should focus on reducing the environmental and socio-economic impact form catastrophic floods, mud-slides and riverbank erosion, specifically in settled areas [21]. Like most of its neighbors in the Western Balkans, the Republic of Serbia faces dangers 
associated with rising temperatures. Increasingly frequent and intense droughts during the last two decades have already caused great damage to the Republic of Serbia in agriculture, and it is expected that production will fall by much than $10 \%$ in the second half of this century. The Serbian agricultural sector is an important part of the national economy, increasing the country's vulnerability to climate change. The Republic of Serbia in agriculture employs $10 \%$ of the workforce and accounts for $26 \%$ of export earnings. With incomplete privatization and incomplete structural reforms, the Republic of Serbia's economy remains in transition. The country's economic challenges include high government spending on wages, pensions, and unemployment; outdated technologies; degraded infrastructure; and low levels of domestic investment. Other problems include the growing need for new government borrowing combined with growing public and private external debt and stagnant levels of foreign investment. An inefficient justice system, high levels of corruption, and an aging population add to the difficulties. Republic of Serbia's strategic position, relatively cheap and skilled labor, and a generous package of incentives for foreign investment are factors conducive to economic growth [12].

\section{Conclusions}

The main objective of this paper is to present the state of climate change in six Western Balkans countries, of which only Croatia is a member of the EU, for the needs of planning activities and initial harmonization with the EU plan to reaching net-zero GHG emissions by 2050 . The paper provides an overview of climate change by country, scenario analysis, and policy recommendations.

Based on the analysis it can be concluded that Croatia as a member of the EU has adopted, and other five Western Balkans countries are in the process of adopting the necessary regulations and strategies towards climate change mitigation, but the implementation of specific activities is at a low level.

Climate change mitigation strategies in Albania for the energy sector include switching to power plants using cleaner energy sources. Initiatives within agriculture focus on improving manure management and grazing systems and crop rotation. In addition, the construction of new landfills with methane recovery and solid waste incinerators is intended to reduce wasterelated emissions. Strategies related to land-use change and forestry include the development of sustainable forestry, the improvement of forest management practices, and the rehabilitation of degraded forest land. The development of Bosnia and Herzegovina's climate change mitigation strategy should include a national mitigation policy related to national economic and development plans; identifying measures and activities necessary for implementation; and provisions for direct government involvement at the entity level. Croatia has implemented several measures to mitigate climate change. The largest percentage of changes occurred in transport, land-use change, forestry, and waste. In the energy sector, the implemented measures included the promotion of the use of renewable energy sources in electricity production, the application of cogeneration and the improvement of energy efficiency in building construction, and also the construction of $1000 \mathrm{MW}$ nuclear power plants by 2024. In the transport sector, biofuel and a program for the promotion of railway transport are being introduced. New measures related to industrial processes are intended to reduce $\mathrm{N}_{2} \mathrm{O}$ emissions in the production of nitric acid and emissions of volatile organic compounds in the use of solvents. New waste measures include avoiding and reducing municipal waste generation, increased recycling of municipal waste, and the use of landfill gas to generate electricity. In agriculture, efficient management of organic manure is promoted, and in the land use and forestry sector, efforts are being made to improve the management of private forests and new forest plantations. The plan to reduce emissions in the Republic of North Macedonia envisages the use of natural gas for electricity production, maximizing the potential of hydropower and improving energy efficiency. Transport measures include improving the energy efficiency of vehicles and public urban and interurban transport. The waste strategy introduces sustainable management and measures for waste selection and recycling, composting, and reduction of land-filled waste. The main strategy in agriculture focuses on manure management and forestry on afforestation. Montenegro has identified emission reduction strategies for each sector. Strategies for the energy sector include combining heat and power generation, increasing the efficiency of industrial boilers and replacing coal with liquefied petroleum gas in industrial boiler rooms, and producing high-temperature heat. Plans for the transport sector envisage the replacement of fossil fuels with alternative fuels and the development of a more efficient transport system. Strategies for agriculture include improving manure management and encouraging organic agriculture. In the land use and forestry sector, Montenegro intends to increase the share of highly productive forests, rehabilitate damaged forests and preserve and improve forest habitats. Republic of Serbia's mitigation plans for the energy sector includes improving energy efficiency and using more renewable energy sources. Automation, monitoring, and use of waste energy are the main strategies for reducing emissions in the field of industrial 
processes. In the transport sector, Republic of Serbia seeks to re-establish an efficient international railway system, repair roads, increase the level and efficiency of river transport and stop the production of leaded petrol. The use of biogas in the production of heat and electricity for local consumption is a key strategy for reducing agricultural emissions, and afforestation is a desirable strategy in the sector of land-use change and forestry. In the waste sector, Republic of Serbia plans to establish regional landfills and increase recycling rates.

The implementation of specific activities is at a low level. The reason for this most often lies in the insufficient commitment of decision-makers to make significant changes in the field of climate change transition (lower level of economic development, lack of investment, preservation of social peace).

Based on all facts mentioned above, the working hypothesis of this paper has been confirmed. The Western Balkans can play an important role in maximizing the impact of the European Green Agreement. This region has a large, developed renewable energy capacity, with a significantly developed hydro-energy capacity. Leaving the Western Balkans outside the European Green Deal could lead to electricity price disparity with EU countries.

\section{Acknowledgements}

The authors would like to thank the Public Scholarship, Development, Disability, and Maintenance Fund of the Republic of Slovenia, Ministry of Education, Science and Sport of the Republic of Slovenia (Grant No: 11081-4/2019), and Ministry of Education, Science and Technological Development of the Republic of Serbia (Grant No: 451-03-9/2021-14/200026) for financial support.

\section{Authors' contributions}

SK analyzed $\mathrm{CO}_{2}$ emission in Western Balkans, SŠ analyzed how climate change affects Western Balkans, and IP analyzed GHG emission in Western Balkans. All authors read and approved the final manuscript.

\section{Funding}

Ministarstvo Prosvete,Nauke i Tehnološkog Razvoja, 451-03-9/2021-14/200026, Snežana Štrbac, Ministrstvo za Izobraževanje,Znanost in Šport, 110814/2019,Sandi Knez, 11081-4/2019, Iztok Podbregar.

\section{Availability of data and materials}

Not applicable.

\section{Declarations}

Ethics approval and consent to participate

Not applicable.

\section{Consent for publication}

Not applicable.

\section{Competing interests}

The authors declare that they have no competing interests.

\section{Author details}

${ }^{1}$ Aviation Career Center, CEO, 2312 Orehova vas, Slovenia. ${ }^{2}$ Institute of Chemistry, Technology and Metallurgy, University of Belgrade, 11000 Belgrade, Republic of Serbia. ${ }^{3}$ Faculty of Organizational Sciences, University of Maribor, 4000 Kranj, Slovenia.
Received: 20 August 2021 Accepted: 6 December 2021

Published online: 03 January 2022

\section{References}

1. IPCC (2018) Global Warming of $1.5^{\circ} \mathrm{C}$. An IPCC Special Report on the impacts of global warming of $1.5^{\circ} \mathrm{C}$ above pre-industrial levels and related global greenhouse gas emission pathways, in the context of strengthening the global response to the threat of climate change, sustainable development, and efforts to eradicate poverty. https://www. ipcc.ch/site/assets/uploads/sites/2/2019/06/SR15_Full_Report_Low_Res. pdf. Accessed 24 June 2021

2. PBES (2019) Summary for policymakers of the global assessment report on biodiversity and ecosystem services of the Intergovernmental Science-Policy Platform on Biodiversity and Ecosystem Services. IPBES secretariat. https://ipbes.net/sites/default/files/inline/files/ipbes_global_ assessment_report_summary_for_policymakers.pdf. Accessed 24 June 2021

3. RP (2019) Global Resources Outlook 2019: Natural resources for the future we want. In Report of the International Resource Panel. United Nations Environment Programme. file:///C:/Users/PC/AppData/Local/Temp/ GRO_2019.pdf. Accessed 25 June 2021

4. EEA (2019) The European environment-state and outlook 2020. Publications Office of the European Union. https://d2ouvy59p0dg6k.cloudfront. net/downloads/soer_2020_executive_summary_embargoed_4_decem ber.pdf. Accessed 25 June 2021

5. The European Green Deal (2019) Communication from the commission to the European parliament, the European council, the council, the European economic and social committee and the committee of the regions. https://ec.europa.eu/info/sites/default/files/european-greendeal-communication_en.pdf. Accessed 26 June 2021

6. United Nations Development Programme UNDP https://sustainabledeve lopment.un.org/post2015/transformingourworld. Accessed 26 June 2021

7. Vulevic A, Castanho RA, Naranjo Gómez JM, Lausada S, Loures L, Cabezas J, Fernández-Pozo L (2021) Cross-border cooperation and adaptation to climate change in Western Balkans Danube area, advances in spatial science. In: Berisha E, Cotella G, Solly A (eds) Governing territorial development in the Western Balkans. Springer, Cham

8. Alfthan B, Krilasevic E, Venturini S, Bajrovic S, Jurek M, Schoolmeester T, Sandei PC, Egerer H, Kurvits T (2015) Outlook on climate change adaptation in the Western Balkan mountains. United Nations Environment Programme. GRIDArendal and Environmental Innovations Association

9. Globevnik L, Snoj L, Šubelj G, Kurnik B (2018) Outlook on water and climate change vulnerability in the Western Balkans. European Topic Centre on inland, coastal and marine waters, Magdeburg

10. Gomes TMC (2019) The European Union accession and climate change policies in the Western Balkan countries, contributions to economics. In: Sequeira T, Reis L (eds) Climate change and global development. Springer, Cham

11. Vuković A, Vujadinović Mandić M (2018) Study on climate change in the Western Balkans region. Printline d.o.o., Sarajevo

12. Bogdanovic J, Nikolayeva L, Novikov V, Siljic A, Simonett O, Egerer H, Sandei PC (2012) Climate change in the West Balkans. ENVSEC, Zoï environment network

13. Kostopoulou E, Jones PD (2005) Assessment of climate extremes in the Eastern Mediterranean. Meteorol Atmos Phys 89:69-85. https://doi.org/ 10.1007/s00703-005-0122-2

14. Lelieveld J, Hadjinicolaou P, Kostopoulou E, Chenoweth J, Maayar ME, Giannakopoulos C, Hannides C, Lange MA, Tanarhte M, Tyrlis E, Xoplaki E (2012) Climate change and impacts in the Eastern Mediterranean and the Middle East. Clim Change 114:667-687. https://doi.org/10.1007/ s10584-012-0418-4

15. Önol B, Semazzi FHM (2009) Regionalization of climate change simulations over the Eastern Mediterranean. J Clim 22:1944-1961. https://doi. org/10.1175/2008JCLI1807.1

16. World Bank (2014) Turn down the heat: confronting the new climate normal. https://openknowledge.worldbank.org/handle/10986/20595. Accessed 28 June 2021

17. Djurdjevic V, Trbić G, Krzic A, Bozanic D (2019) Projected changes in multiday extreme precipitation over the Western Balkan region. In: Leal Filho 
W, Trbic G, Filipovic D (eds) Climate change adaptation in Eastern Europe, climate change management. Springer, Cham

18. Kotlarski S, Bosshard T, Lüthi D, Pall P, Schär C (2011) Elevation gradients of European climate change in the regional climate model COSMO-CLM. Clim Change 112:189-215. https://doi.org/10.1007/s10584-011-0195-5

19. Hoppe T, van den Berg MM, Coenen FH (2014) Reflections on the uptake of climate change policies by local governments: facing the challenges of mitigation and adaptation. Energ Sustain Soc 4:8. https://doi.org/10. 1186/2192-0567-4-8

20. Kharin W, Zwiers FW, Zhang X, Wehner M (2013) Changes in temperature and precipitation extremes in the CMIP5 ensemble. Clim Change 119:345-357. https://doi.org/10.1007/s10584-013-0705-8

21. World Bank (2003) Water Resources Management in South Eastern Europe, Volume I. Issues and Directions. https://openknowledge.world bank.org/handle/10986/15280. Accessed 28 June 2021

22. Gallop P, Vejnović I, Davor P (2019) Western Balkans hydropower-who pays, who profits? How renewables incentives have fed the small hydropower boom and what needs to change. CEE Bankwatch Network, WWF

23. UNECE United Nations Economic Commission for Europe (2011) Second Assessment of Transboundary rivers, lakes and groundwaters: executive summary. Zoï Environment Network. https://unece.org/DAM/env/water/ publications/assessment/English/Executive_Summary_EN_web.pdf. Accessed 29 June 2021

24. EEA European Environment Agency (2010) Environmental trends and perspectives in the Western Balkans: future production and consumption patterns. https://www.eea.europa.eu/publications/western-balkans. Accessed 29 June 2021

25. Arnell NW, Gosling SN (2013) The impacts of climate change on river flow regimes at the global scale. J Hydrol 486:351-364. https://doi.org/10. 1016/j.jhydrol.2013.02.010

26. Schneider C, Laize CLR, Acreman M, Florke M (2013) How will climate change modify river flow regimes in Europe? Hydrol Earth Syst Sc 17:325339. https://doi.org/10.5194/hess-17-325-2013

27. EEA European Environment Agency (2008) National emissions reported to the UNFCCC and to the EU greenhouse gas monitoring mechanism. https://www.eea.europa.eu/data-and-maps/data/national-emissionsreported-to-the-unfccc-and-to-the-eu-greenhouse-gas-monitoringmechanism-14. Accessed 29 June 2021.

28. Volk T, Erjavec E, Mortensen K (2014) Agricultural policy and European integration in South-Eastern Europe. FAO. http://www.fao.org/3/i4166e/ i4166e.pdf. Accessed 29 June 2021

29. World Bank (2012) Employment in agriculture (per cent of total employment). World Bank. https://data.worldbank.org/indicator/SL.AGR.EMPL.ZS. Accessed 29 June 2021

30. Gocic M, Trajkovic S (2014) Spatiotemporal characteristics of drought in Serbia. J Hydrol 510:110-123. https://doi.org/10.1016/j.jhydrol.2013.12. 030

31. Olesen JE, Bindi M (2002) Consequences of climate change for European agricultural productivity, land use and policy. Eur J Agron 6:239-262. https://doi.org/10.1016/S1161-0301(02)00004-7

32. Giannakopoulos C, Le Sager P, Bindi M, Moriondo M, Kostopoulou E, Goodess CM (2009) Climatic changes and associated impacts in the Mediterranean resulting from a $2^{\circ} \mathrm{C}$ global warming. Glob Planet Change 68:209-224. https://doi.org/10.1016/j.gloplacha.2009.06.001

33. Sutton WR, Srivastava JP, Neumann JE (2013) Looking beyond the horizon: how climate change impacts and adaptation responses will reshape agriculture in Eastern Europe and Central Asia. World Bank. https:// documents1.worldbank.org/curated/en/676601468249642651/pdf/Look ng-beyond-the-horizon-how-climate-change-impacts-and-adaptationresponses-will-reshape-agriculture-in-Eastern-Europe-and-Central-Asia. pdf. Accessed 30 June 2021

34. Markus-Johansson M, Mesquita B, Nemeth A, Dimovski M, Monnier C Kiss-Parciu P (2010) Illegal logging in South Eastern Europe: Regional Report. REC Regional Environment Centre for Central and Eastern Europe. http://documents.rec.org/publications/lllegal_Logging_in_South_Easte rn_Europe_Regional_Report_EN_OCT 2010.pdf. Accessed 30 June 2021

35. Parviainen $J$ (2005) Virgin and natural forests in the temperate zone of Europe. For Snow Landsc Res 79:9-18

36. Mátyás C (2010) Forecasts needed for retreating forests. Nature 464:1271. https://doi.org/10.1038/4641271a
37. IPCC Intergovernmental Panel on Climate Change (2007) Climate change 2007: impacts, adaptation and vulnerability. Contribution of Working Group II to the Fourth Assessment Report of the Intergovernmental Panel on Climate Change. Cambridge University Press. Available via https:// www.ipcc.ch/site/assets/uploads/2018/03/ar4_wg2_full_report.pdf. Accessed 1 July 2021.

38. EU Biodiversity Strategy for 2030 (2010) Communication from the commission to the European parliament, the council, the European economic and social committee and the committee of the regions. European Commission. Available via https://ec.europa.eu/info/sites/default/files/ communication-annex-eu-biodiversity-strategy-2030_en.pdf. Accessed 11 October 2021.

39. Knez S (2021) A model of managerial competences in aviation microenterprises. Dissertation, University of Maribor.

40. Dilley M, Chen RS, Deichmann U, Lerner-Lam AL, Arnold M, Agwe J, Buys P, Kjekstad O, Lyon B, Yetman G (2005) Natural disaster hotspots: a global risk analysis. The World Bank Hazard Management Unit, Washington, D.C

41. World Bank (2009) Adapting to climate change in Europe and Central Asia. World Bank. https://documents1.worldbank.org/curated/en/12718 1468024643244/pdf/489480ESWOECA010Box338935B01PUBLIC1.pdf. Accessed 1 July 2021

42. Van Vliet MTH, Yearsley JR, Ludwig F, Vögele S, Lettenmaier DP, Kabat P (2012) Vulnerability of U.S. and European electricity supply to climate change. Nat Clim Change 2:676-681. https://doi.org/10.1038/nclimate15 46

43. Hamududu B, Killingtveit A (2012) Assessing climate change impacts on global hydropower. Energies 5:305-322. https://doi.org/10.3390/en502 0305

44. McDermott GR, Nilsen $\varnothing A$ (2014) Electricity prices, river temperatures, and cooling water scarcity. Land Econ 90:31-48. https://doi.org/10.2139/ ssrn. 1941820

45. EC European Commission (2013) An EU Strategy on adaptation to climate change. Communication from the Commission to the European Parliament, the Council, the European Economic and Social Committee and the Committee of Regions. http://eur-lex.europa.eu/LexUriServ/LexUr iServ.do?uri=COM:2013:0216:FIN:EN:PDF. Accessed 1 July 2021

46. Ben Othman A, Ouni A, Besbes M (2020) Deep learning-based estimation of PV power plant potential under climate change: a case study of El Akarit, Tunisia. Energ Sustain Soc 10:34. https://doi.org/10.1186/ s13705-020-00266-1

47. Röder M, Thornley P (2016) Bioenergy as climate change mitigation option within a $2^{\circ} \mathrm{C}$ target-uncertainties and temporal challenges of bioenergy systems. Energ Sustain Soc 6:6. https://doi.org/10.1186/ s13705-016-0070-3

\section{Publisher's Note}

Springer Nature remains neutral with regard to jurisdictional claims in published maps and institutional affiliations.

Ready to submit your research? Choose BMC and benefit from:

- fast, convenient online submission

- thorough peer review by experienced researchers in your field

- rapid publication on acceptance

- support for research data, including large and complex data types

- gold Open Access which fosters wider collaboration and increased citations

- maximum visibility for your research: over $100 \mathrm{M}$ website views per year

At BMC, research is always in progress.

Learn more biomedcentral.com/submissions 